\title{
Humoral anti-KLH responses in cancer patients treated with dendritic cell-based immunotherapy are dictated by different vaccination parameters
}

\author{
Erik H. J. G. Aarntzen • I. Jolanda M. de Vries • Joop H. Göertz • Marjo Beldhuis-Valkis • \\ Huberdina M. L. M. Brouwers - Mandy W. M. M. van de Rakt • Renate G. van der Molen • \\ Cornelis J. A. Punt · Gosse J. Adema · Paul J. Tacken · Irma Joosten · Joannes F. M. Jacobs
}

Received: 9 February 2012/Accepted: 4 April 2012/Published online: 21 April 2012

(C) The Author(s) 2012. This article is published with open access at Springerlink.com

\begin{abstract}
Purpose Keyhole limpet hemocyanin (KLH) attracts biomedical interest because of its remarkable immunostimulatory properties. Currently, KLH is used as vaccine adjuvant, carrier protein for haptens and as local treatment for bladder cancer. Since a quantitative human anti-KLH assay is lacking, it has not been possible to monitor the dynamics of KLH-specific antibody $(\mathrm{Ab})$ responses after in vivo KLH exposure. We designed a quantitative assay to measure KLH-specific Abs in humans and retrospectively studied the relation between vaccination parameters and the vaccine-induced anti-KLH Ab responses.
\end{abstract}

Electronic supplementary material The online version of this article (doi:10.1007/s00262-012-1263-z) contains supplementary material, which is available to authorized users.

E. H. J. G. Aarntzen · I. J. M. de Vries · J. F. M. Jacobs Department of Medical Oncology, Radboud University Nijmegen Medical Centre, Nijmegen, The Netherlands

E. H. J. G. Aarntzen - I. J. M. de Vries .

M. W. M. M. van de Rakt · G. J. Adema ·

P. J. Tacken · J. F. M. Jacobs

Department of Tumor Immunology, Nijmegen Centre for Molecular Life Sciences, Radboud University Nijmegen

Medical Centre, Nijmegen, The Netherlands

J. H. Göertz · M. Beldhuis-Valkis · H. M. L. M. Brouwers

R. G. van der Molen · I. Joosten · J. F. M. Jacobs ( $₫)$

Department of Laboratory Medicine, Laboratory Medical Immunology, Radboud University Nijmegen Medical Centre, Geert Grooteplein 10, 6525 GA Nijmegen, The Netherlands e-mail: H.Jacobs@labgk.umcn.nl

C. J. A. Punt

Department of Medical Oncology, Academic Medical Centre, Amsterdam, The Netherlands
Experimental design Anti-KLH Abs were purified from pooled serum of melanoma patients who have responded to $\mathrm{KLH}$ as a vaccine adjuvant. Standard isotype-specific calibration curves were generated to measure KLH-specific $\mathrm{Ab}$ responses in individual serum samples using ELISA.

Results KLH-specific IgM, IgA, IgG and all IgG-subclasses were accurately measured at concentrations as low as $20 \mu \mathrm{g} / \mathrm{ml}$. The intra- and inter-assay coefficients of variation of this ELISA were below 6.7 and $9.9 \%$, respectively. Analyses of 128 patients demonstrated that mature DC induced higher levels of KLH-specific IgG compared to immature DC, prior infusion with anti-CD25 abolished $\operatorname{IgG}$ and $\operatorname{IgM}$ production and patients with locoregional disease developed more robust IgG responses than advanced metastatic melanoma patients.

Conclusions We present the first quantitative assay to measure KLH-specific Abs in human serum, which now enables monitoring both the dynamics and absolute concentrations of humoral immune responses in individuals exposed to KLH. This assay may provide a valuable biomarker for the immunogenicity and clinical effectiveness of KLH-containing vaccines and therapies.

Keywords Adjuvant · Dendritic cell · Humoral response · Immunocompetence $\cdot$ Keyhole limpet hemocyanin .

Vaccine

\section{Introduction}

Keyhole limpet hemocyanin (KLH) is a high-molecularweight glycoprotein, purified from a marine snail species called Megathura crenulata, that induces both cell-mediated and humoral responses in animals and humans. Because of its high immunogenicity and low toxicity, KLH 
is used for a variety of basic research and clinical applications [1]. KLH was introduced into the clinic in 1967 to assess immunocompetence of individuals [2]. Later, KLH became a standard carrier for the production of antibodies (Abs) to small molecule haptens such as peptides and oligosaccharides [1]. Besides this, KLH is used as a local treatment for patients with bladder cancer [3]. Finally, KLH has progressed into clinical trials as either adjuvantor immunomonitoring tool in a variety of vaccines directed against cancer $[4,5]$ or infectious diseases [6].

Dendritic cells (DCs) are potent antigen presenting cells and play a central role in the induction and maintenance of antigen-specific immunity. Antigen-specific immune responses in cancer patients can be induced by exploiting autologous DCs [7]. In our institute, autologous DCs are activated ex vivo and loaded with tumor antigens. KLH is added to the vaccine both as a nonspecific $\mathrm{T}$ helper cell stimulus and to facilitate monitoring of the vaccineinduced immune responses [8-10]. After DC injection, the cells migrate toward the lymph nodes where they present their processed antigens to the adaptive arm of the immune system, inducing antigen-specific $\mathrm{T}$ and $\mathrm{B}$ cell responses [11].

In the last decade, several parameters of DC-based therapy have been optimized to improve vaccine-induced immunological responses, particularly in melanoma patients [12]. For example, it is well-accepted that the use of mature DC is superior to immature DC [13] and pretreatment with anti-CD25 antibodies does not improve immunological responses [14]. The route of administration largely dictates the failure or success of the induced immunological responses $[15,16]$. Similarly, evidence is accumulating that the use of nonspecific helper epitopes, such as KLH, is critical to the induction of effective antitumor responses [17]. In these clinical trials, much effort has been put in the detection of tumor-antigen-specific immune responses, for example ELIspots [18, 19], T cell receptor (TCR) frequency assessment [20] and analyses of skin test biopsies [21, 22]. These assays have multiple disadvantages; the assays are laborious, have limited sensitivity, often lack association with clinical outcome and are difficult to standardize [23, 24]. Strikingly, not much attention has been paid to the dynamics, levels and patterns of the vaccine-induced antiKLH humoral responses in clinical trials, which could provide a simple and direct method for evaluation of vaccineinduced immune responses.

Assays to monitor cellular [25, 26] and humoral [27-29] immune responses against KLH have been developed to facilitate optimal use of biomedical KLH applications. The enzyme-linked immunosorbent assay (ELISA) proved a simple and sensitive assay to measure serological Abs, and in 1979, the first quantitative assay to detect KLH-specific
$\mathrm{Ab}$ in mice was published [27]. Five years later, the first ELISA was developed to detect KLH-specific Ab in human serum [28]. Currently, all published human anti-KLH ELISA's report $\mathrm{Ab}$ responses in arbitrary units based on optical density values, which yields relative units/values only.

Because of the lack of a quantitative human anti-KLH assay, so far it has not been possible to monitor the dynamics of KLH-specific Ab responses after in vivo KLH exposure. It was neither possible to link the concentration of induced KLH Abs either to the immunocompetence of an individual or to the immunogenicity of KLH-containing vaccines.

In this study, we present the first quantitative ELISA to measure KLH-specific Abs in human serum, measuring both IgG, IgA, IgM and all IgG-subclasses. We demonstrate that it is now possible to monitor the dynamics of both KLH-specific $\mathrm{Ab}$ levels and Ab class-switching in individuals who are repeatedly exposed to KLH. Furthermore, we retrospectively analyzed the humoral anti-KLH responses of melanoma patients enrolled in our clinical trials investigating dendritic cell-based vaccinations. Our data confirm that individuals exposed to KLH react to it as a primary immunogen, inducing a characteristic primary immune response. Moreover, analyses of our clinical DCbased vaccination protocols demonstrated that variations in the vaccination parameters dramatically influence both the quantity and the quality of the induced humoral response.

\section{Materials and methods}

Preparation of serum pool containing anti-KLH antibodies

Serum was pooled from HLA-A*02:01 melanoma patients and colorectal cancer patients who were previously vaccinated with KLH-pulsed dendritic cells (DCs). To generate a serum pool with a broad spectrum of KLH-specific Abs, sera were obtained from 28 patients enrolled in different clinical trials within our institute in which the maturation status of the DCs and the route of vaccine administration varied per clinical trial $[13-15,30,31]$. For the exact details regarding the vaccination protocols and the patient inclusion, we refer to these individual studies. In all studies, KLH was added at day 3 of the DC culture at a concentration of $10 \mu \mathrm{g} / \mathrm{ml}$ and patients received maximum three vaccination cycles of 3 bi-weekly vaccinations at a 6-month interval. Informed consent was obtained from all patients, and the study was approved by our Institutional Review Board. 
Purification of KLH-specific antibodies

Using a KLH-coated column (Alpha Diagnostic International, San Antonio, TX, USA), $18 \mathrm{ml}$ starting serum pool of KLH-specific Abs was isolated from the above-mentioned trials. Prior to use, the column was extensively washed with elution buffer $(0.1 \mathrm{M}$ glycine $\mathrm{HCl} \mathrm{pH} 2.5)$ to dissociate multimeric KLH and remove monomers that were not covalently linked to the Sepharose bed. Subsequently, the column was equilibrated with PBS, followed by application of the pooled serum, washed with PBS and elution of the KLH-specific Abs with elution buffer and neutralized with Tris/HCL pH 9.0. The KLH-specific IgM-, IgA- and IgG-Abs in the eluate with a volume of $1,380 \mu \mathrm{l}$ were quantified using nephelometry on an Immage apparatus (Beckman Coulter, Brea, CA, USA), IgG subclasses were measured on a BNII (Siemens, Münich, Germany) using reagents of The Binding Site (Birmingham, UK) all according to the manufacturers protocol. Following this approach, a $1.4 \mathrm{ml}$ polyclonal anti-KLH stock was obtained in which all major immunoglobulin isotypes and IgG subclasses were represented (Supplementary Table 1, available online). This stock of purified and quantified $\mathrm{KLH}$-specific Abs was stored at $-80{ }^{\circ} \mathrm{C}$ and used to generate standard curves for the quantitative ELISA. All experiments in this manuscript were performed with one single calibrated work standard of $34 \mathrm{ml}$ created from 28 different patients.

\section{Quantitative anti-KLH ELISA}

Ninety-six-well plates were coated for $18 \mathrm{~h}$ at $4{ }^{\circ} \mathrm{C}$ with $5 \mu \mathrm{g} / \mathrm{mL} \mathrm{KLH}$ (Biosyn, Carlsbad, CA, USA) in PBS in a total volume of $120 \mu \mathrm{L}$ per well, and wells were subsequently blocked with skimmed milk powder. After washing the plates, different concentrations of patient serum were added for $1 \mathrm{~h}$ at room temperature. To prepare suitable standard curves for the anti-KLH ELISA's, the work standard was serially diluted to establish a 7-point standard curve for each Ab isotype (Supplementary Figure 1, available online). For analysis of individual patient samples, a standard curve was added to each plate. After washing, specific Abs against human IgM or IgA or total IgG or IgG1 or IgG2 or IgG3 or IgG4 labeled with horseradish peroxidase (Invitrogen, San Diego, CA, USA) at 1:500 were added to the wells as $100 \mu \mathrm{L}$ aliquots. The isotype-specific secondary Abs allow quantification of both human IgM, IgA, total IgG, IgG1, IgG2, IgG3 and IgG4 KLH-specific Abs. After a further incubation for $1 \mathrm{~h}$ at room temperature and a final washing with buffer, peroxidase activity was revealed using 3,3' 5,5-tetramethyl-benzide as substrate. The reaction was stopped with sulfuric acid, and samples were measured in a microtiter plate reader at $450 \mathrm{~nm}$. A uniform detection limit of the anti-KLH ELISA's was arbitrarily determined at $20 \mu \mathrm{g} / \mathrm{ml}$. This detection limit falls within the lower linear part of all anti-KLH calibration curves. Precision and linearity were determined according to the Clinical and Laboratory Standards Institute protocols EP5 and EP6, respectively.

\section{Statistical analysis}

Precision and linearity were analyzed using EP Evaluator 9 software, and all other statistical analyses were performed by Graphpad Prism 5.0. For the comparison of different vaccination protocols, patients were grouped based on similar protocol characteristics, such as stage of disease on entry, route of administration, pretreatment with anti-CD25 antibodies, additional treatment with interleukin-2 (IL-2) or the method of tumor antigen loading. For the comparison of 2 groups, all the above-mentioned protocol characteristics should be similar, except for the single parameter under investigation. Maximum KLH-specific Ab responses, out of at least 3 samples obtained at standard time points during the first cycle, were compared, as this reflects the individual's competence to generate a humoral response. Nonparametric Mann-Whitney test was performed to compare the $\mathrm{KLH}$-specific $\mathrm{Ab}$ responses of similar isotypes in two groups of melanoma patients exposed to KLH. A two-tailed $p$ value $<0.05$ was considered significant.

\section{Results}

Assay performance and validation

To evaluate the precision of the assay, pooled serum samples were measured in 2 replicates per run, 1 run per day for a minimum of 20 runs. The resulting anti-KLH ELISA's have an intra-assay imprecision, denoted by the coefficient of variation (CV), that ranged from 4.3 to $6.7 \%$. The interassay CV varied from 6.4 to $9.9 \%$ (Table 1). To test for assay-linearity, we serially diluted 2 individual patient serum samples per KLH assay isotype at a minimum of 5 levels, assayed in quadruplicate. The results yielded slopes ranging from 0.918 to 1.036 , and the coefficients of determination $\left(\mathrm{R}^{2}\right)$ ranged from 0.991 to 0.998 (Fig. 1). A method-comparison analysis was not possible, as there is no golden standard quantitative human anti-KLH available.

Monitoring the dynamics of humoral anti-KLH responses in individual patients

Repetitive serum sampling of individual patients enrolled in clinical trials on dendritic cell-based vaccinations allows in-depth monitoring of the kinetics of the KLH-specific $\mathrm{Ab}$ 
Table 1 Performance assessment of the anti-KLH ELISA assays

\begin{tabular}{|c|c|c|c|c|c|c|c|c|c|c|c|c|c|c|}
\hline & $\mathrm{IgG}_{\text {total }}$ & & $\mathrm{IgG}_{1}$ & & $\mathrm{IgG}_{2}$ & & $\mathrm{IgG}_{3}$ & & $\mathrm{IgG}_{4}$ & & $\operatorname{Ig} \mathrm{A}_{\text {total }}$ & & $\operatorname{IgM}_{\text {total }}$ & \\
\hline Mean $(\mathrm{mg} / \mathrm{L})$ & 478.0 & & 282.0 & & 80.4 & & 5.0 & & 76.3 & & 22.8 & & 719.7 & \\
\hline Variation & Intra & Inter & Intra & Inter & Intra & Inter & Intra & Inter & Intra & Inter & Intra & Inter & Intra & Inter \\
\hline SD & 22.1 & 30.5 & 13.6 & 25.1 & 5.4 & 7.1 & 0.22 & 0.40 & 4.1 & 5.1 & 1.1 & 2.2 & 44.4 & 71.6 \\
\hline CV (\%) & 4.6 & 6.4 & 4.8 & 8.9 & 6.7 & 7.1 & 4.3 & 7.9 & 5.4 & 6.7 & 5.0 & 9.7 & 6.2 & 9.9 \\
\hline
\end{tabular}

$\mathrm{CV}$, coefficient of variation; intra, intra-assay imprecision; inter, inter-assay imprecision

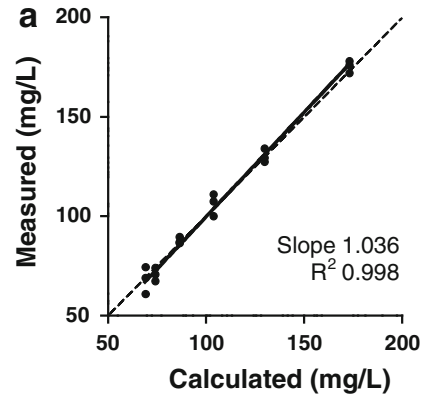

Fig. 1 Serial dilution linearity of the anti-KLH ELISA. Serum samples of patients exposed to KLH were serially diluted with assay buffer and measured in quadruplicate. The results for linearity of the ELISA for the anti-KLH isotypes $\operatorname{IgG}$ (a) $\operatorname{IgA}$ (b) and $\operatorname{IgM}$ (c) are

responses during therapy. In the majority of patients, we detected the first KLH-specific Abs after the 2nd or 3rd vaccination. We show one representative melanoma patient who had detectable levels of KLH-specific IgM Abs after the second vaccination (Fig. 2a). The IgM response was followed by KLH-specific IgG Abs and after four vaccinations also by IgA Abs. Ab titers were drastically decreased between vaccination cycles and after the last vaccination.

IgG subclass analysis showed that IgG1 predominantly contributed to the $\mathrm{KLH}$-specific $\mathrm{IgG}$ response in this patient (Fig. 2b). This example demonstrates that the KLH $\mathrm{Ab}$ response strongly depends on the schedule of KLH exposure and the time point of serum sampling. One vaccinated patient received 9 vaccinations that did not contain $\mathrm{KLH}$, because of a severe shellfish allergy. We detected no KLH-specific Abs in this specific patient (Fig. 2c, d), demonstrating that KLH-specific $\mathrm{Ab}$ responses are caused specifically by the KLH added to the vaccine and not by the vaccine itself. The high specificity of the anti-KLH ELISA is further illustrated by the fact that none of the 57 tested patients had detectable KLH-specific Abs prior to vaccination (Fig. 3a, bars indicated by 'before').

Variations in vaccination parameters have major influence on the levels and patterns of humoral anti-KLH responses

Another application of this novel assay is that it allows the comparison of the humoral immunogenicity of different shown. Calculated concentrations are based on stock-concentration and dilution factor. Slopes and coefficients of determination $\left(\mathrm{R}^{2}\right)$ are indicated in each panel. The line of identity is indicated by the dashed line

KLH-containing interventions. To demonstrate this, we performed subgroup analyses in a total of 118 melanoma patients, 43 stage III and 85 stage IV, who received dendritic cell-based vaccinations according to different protocols (Table 2).

Pretreatment with a single dose of intravenous humanized monoclonal anti-CD25 antibody (Daclizumab) significantly reduced the overall anti-KLH Ig responses (Fig. 3a). The mean level of anti-KLH IgG without pretreatment (protocol $5, n=22$ ) was $142 \mathrm{mg} / \mathrm{L}$ compared to $18 \mathrm{mg} / \mathrm{L}$ after pretreatment (protocol $4, n=13, p=$ 0.0267). With regard to anti-KLH IgA, the mean levels were $5 \mathrm{mg} / \mathrm{L}$ with no pretreatment and $2 \mathrm{mg} / \mathrm{L}$ with pretreatment; for anti-KLH IgM, this was $157 \mathrm{mg} / \mathrm{L}$ compared to $7 \mathrm{mg} / \mathrm{L}$, respectively $(p=0.0275)$.

Vaccination with immature DC (protocol $1, n=9$ ) barely induced anti-KLH antibodies compared to vaccination with mature DC (protocol 5, $n=22$ ) (Fig. 3b). Anti$\mathrm{KLH}$ IgG antibodies were detected in $2 / 9$ patients upon immature DC vaccination and in $12 / 22$ patients after vaccination with mature DC, mean $9 \mathrm{mg} / \mathrm{L}$ and $142 \mathrm{mg} / \mathrm{L}$, respectively ( $p=0.0600)$. Anti-KLH IgM antibodies were induced in the same patients, 2/9 patients after immature DC vaccination and $9 / 22$ patients after mature DC vaccination, to similar extend, 147 mean $\mathrm{mg} / \mathrm{L}$ and $157 \mathrm{mg} / \mathrm{L}$, respectively $(p=0.4157)$.

As expected, the method of loading the tumor antigens onto the dendritic cells, either pulsing with defined peptides (protocol 3, $n=24$ ) or electroporation with mRNA 

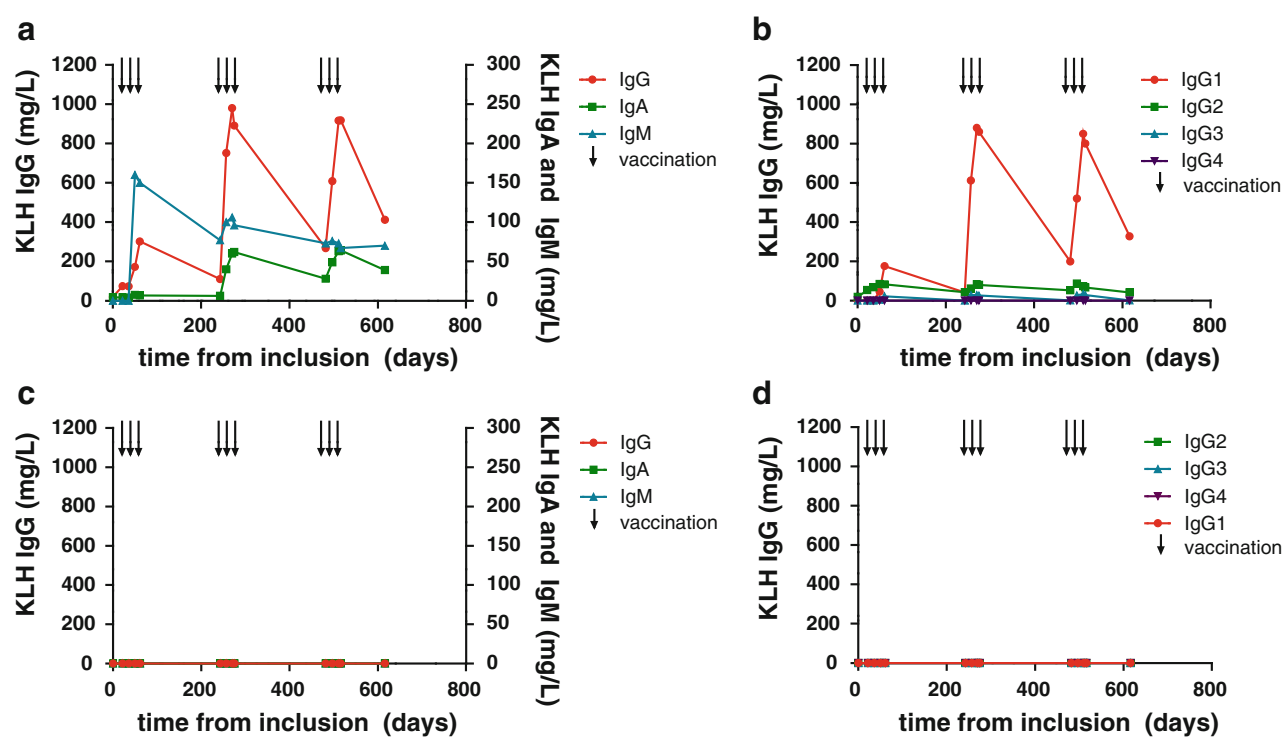

Fig. 2 A detailed characterization of KLH-specific antibody responses in individual patients, two examples. Two patients who received 9 vaccinations of KLH-loaded dendritic cells over a period of 18 months are characterized in detail for KLH-specific antibody responses. Each vaccination is indicated by a black arrow. One patient had a robust humoral response, the kinetics of the KLH-

encoding the tumor antigens (protocol $2, n=17$ ), did not affect the concentration or the pattern of vaccine-induced anti-KLH humoral responses (Fig. 3c).

Combined intravenous/intradermal vaccination (protocol $5, n=22$ ) induced significantly more anti-KLH IgM antibodies as compared to intranodal vaccination (protocol 2 and $3, n=41$ ), mean $157 \mathrm{mg} / \mathrm{L}$ and $27 \mathrm{mg} / \mathrm{L}$, respectively ( $p=0.0222$ ), but no differences in IgG or IgA levels were noted (Fig. 3d).

We observed significantly higher anti-KLH IgG titers in melanoma patients who were vaccinated adjuvant to radical lymph node dissection (stage III) compared to melanoma patients with irresectable locoregional disease or distant metastatic disease (stage IV). Mean concentrations of all isotypes were at least two times higher in stage III patients compared to stage IV melanoma patients (Fig. 3e). However, the most prominent was anti-KLH IgG, mean $310 \mathrm{mg} / \mathrm{L}$ in stage III patients (protocol $6, n=43$ ) compared to $94 \mathrm{mg} / \mathrm{L}$ in stage IV patients (protocol 2 and 3, $n=41), p=0.0002$.

\section{Discussion}

KLH is widely used for biomedical applications because of its remarkable immunogenic properties. In the current study, we describe a novel, highly sensitive and quantitative, sandwich ELISA standardized to measure $\operatorname{IgM}, \operatorname{IgA}$ and $\operatorname{IgG}$ Abs specific for KLH. We demonstrate that it is specific $\operatorname{IgG}$, IgA and $\operatorname{IgM}$ responses are shown in (a). In b, the $\operatorname{IgG}$ immune response is subdivided into the four IgG subclasses, demonstrating that IgG1 predominantly contributes to the KLHspecific immune response in this patient. The second patient received vaccinations with DC not loaded with KLH. In this patient, KLH-specific antibody responses were completely absent $(\mathbf{c}, \mathbf{d})$

now possible to monitor the dynamics and concentrations of humoral KLH-specific immune responses in individuals exposed to KLH and in clinical trials. Importantly, we show that vaccine-induced KLH-specific humoral responses largely depend on variations in vaccination parameters in DC-based clinical trials.

Using our novel anti-KLH ELISA, we found that melanoma patients exposed to KLH-loaded DCs often initially develop KLH-specific IgM Abs, which is associated with a primary immune response as was expected from the literature [32]. After subsequent vaccinations in our patients, this is usually followed by class-switching and the production of KLH-specific IgG Abs, suggestive for a secondary immune response. This secondary immune response is accompanied by KLH-specific $\operatorname{IgA} \mathrm{Abs}$ in a minority of patients. In general, Ab-isotype switching and the identity of the immunoglobulin subclasses is regulated by cytokines and $\mathrm{B}$ cell activators [33]. In this respect, $\mathrm{Ab}$ responses in terms of isotype and subclass will be influenced by the route and conditions under which KLH is administered. In our studies, in which all individuals were exposed to KLH-loaded cytokine-matured DCs, IgG1 was the predominant subclass produced. We hypothesize that the method of KLH exposure and/or individual patient characteristics can result in significant skewing of the $\operatorname{IgG}$ subclass response.

We further demonstrate that, using this novel assay, it is now possible to link the concentration of induced KLH-specific Abs to the humoral immunogenicity of the 

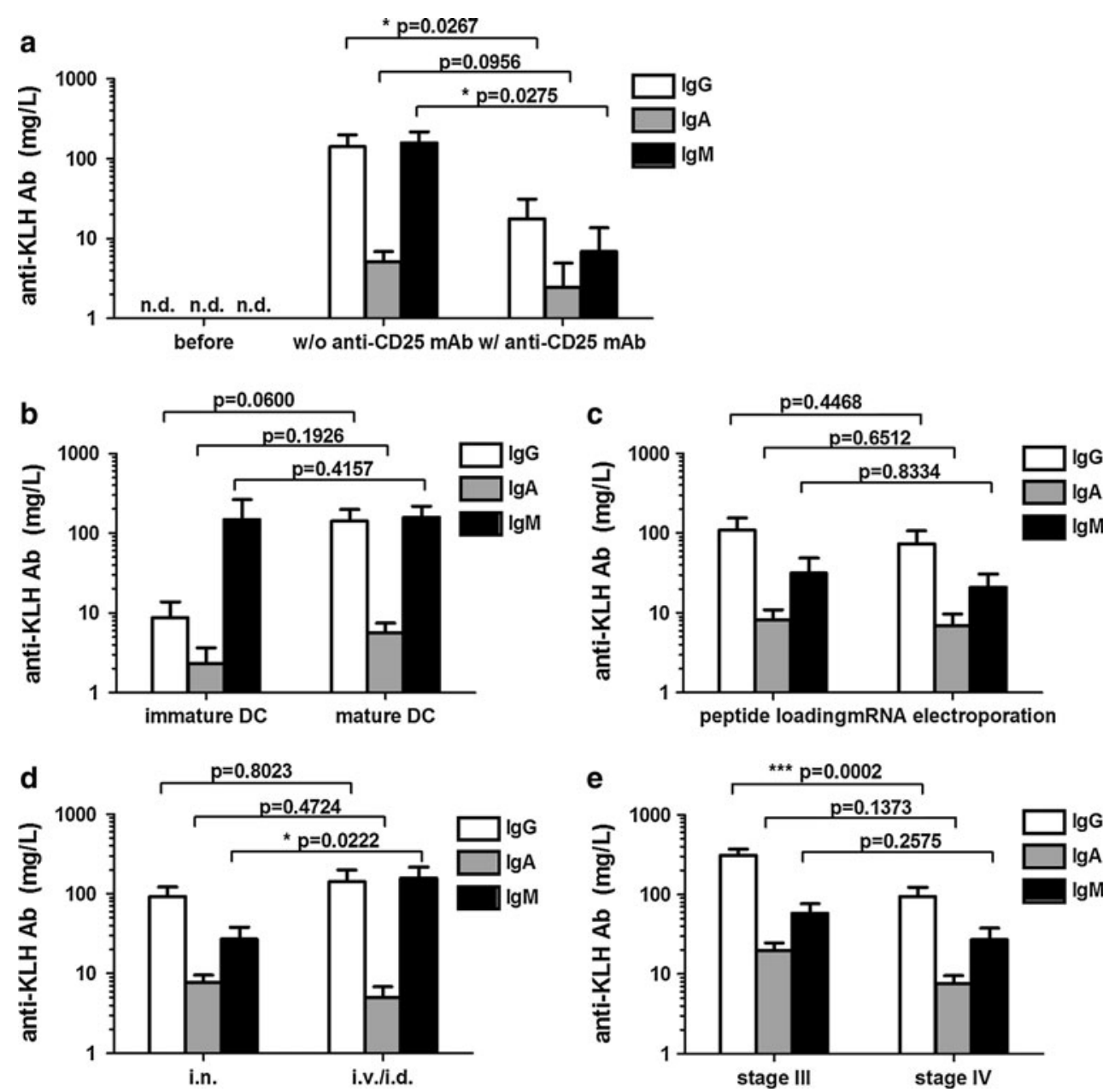

Fig. 3 Variations in vaccination parameters induce different humoral anti-KLH responses. In total, 128 melanoma patients were exposed to KLH by 3 bi-weekly vaccinations containing KLH-loaded DC. None of the 35 patients tested (protocols 4 and 5) had KLH-specific antibodies prior to vaccination (a). KLH-specific $\mathrm{Ab}$ responses compared between a patients treated with or without daclizumab prior to the KLH exposure; b patients vaccinated with immature or

mature KLH-loaded DC; c peptide-loaded or mRNA-transfected KLH-loaded DC; $\mathbf{d}$ intranodal or intravenous/intradermal routes of administration and e patients with locoregional metastatic disease or distant metastatic disease at inclusion. Mean levels of KLH-specific $\operatorname{IgG}$ (white bars), IgA (gray bars) and IgM (black bars) antibodies are shown in $\mathrm{mg} / \mathrm{L}$. Error bars indicate standard error of the mean; $N d$ not detected

Table 2 Patients and protocol characteristics

\begin{tabular}{|c|c|c|c|c|c|c|}
\hline $\begin{array}{l}\text { Protocol } \\
\text { nr. }\end{array}$ & Stage & $\begin{array}{l}\mathrm{Nr} \text { of } \\
\text { patients }\end{array}$ & $\begin{array}{l}\text { Maturation } \\
\text { status }\end{array}$ & $\begin{array}{l}\text { Route of } \\
\text { administration }\end{array}$ & $\begin{array}{l}\text { Anti-CD25 } \\
\text { pretreatment }\end{array}$ & Method of Ag-loading \\
\hline 1 & IV & 9 & Immature & i.v./i.d. & No & Peptide pulsing \\
\hline 2 & IV & 17 & Mature & i.n. & No & mRNA electroporation \\
\hline 3 & IV & 24 & Mature & i.n. & No & Peptide pulsing \\
\hline 4 & IV & 13 & Mature & i.v./i.d. & Yes & Peptide pulsing \\
\hline \multirow[t]{2}{*}{5} & IV & 22 & Mature & i.v./i.d. & No & Peptide pulsing \\
\hline & Total & 85 & & & & \\
\hline \multirow[t]{2}{*}{6} & III & 43 & Mature & i.n. & No & $\begin{array}{l}\text { Peptide pulsing or mRNA } \\
\text { electroporation }\end{array}$ \\
\hline & Total & 43 & & & & \\
\hline
\end{tabular}

KLH-containing DC-based vaccines used in our institute. In our cohort of patients with metastatic melanoma, we have found that adjustments in the vaccination protocol can significantly affect the humoral responses against KLH. We show for example that a single dose of daclizumab, a humanized monoclonal anti-CD25 $\mathrm{Ab}$, prior to the injection 
of KLH-loaded DCs almost completely abolishes the KLHspecific humoral response. Blocking CD25 on activated T cells and regulatory $\mathrm{T}$ cells greatly reduces the capacity of the immune system to respond to de novo antigens. The in vivo effects of daclizumab on $\mathrm{T}$ cells are well documented [34], but the effects of daclizumab on humoral immune responses were largely unexplored. Although injected prior to vaccination, circulating daclizumab may bind to CD25expressing vaccinated DC, providing yet another possible explanation for the strongly reduced vaccine-induced humoral responses to KLH. The maturation status of the DCs is another parameter that strongly affects humoral immunogenicity of the vaccine. We previously demonstrated that more effective cellular immune responses are induced with mature DCs compared to immature DCs [13]. Now we demonstrate that mature DC also generate stronger humoral immune responses and are essential for efficient immunoglobulin class-switching. In addition, we show that there is no significant difference in the KLH-specific IgG and IgA responses when the KLH-vaccine is administered intravenously/intradermally or intranodally in melanoma patients. However, intravenous/intradermal injections tend to result in increased KLH-specific IgM responses compared to intranodal injection. In case of differential tumor antigen loading onto the DC, we would not expect different KLH responses since in all protocols, the DC are pulsed with KLH at day 3 after isolation, and loading with tumor antigen occurs just before administration. Indeed, with regard to different methods of tumor antigen loading, we did not detect differences in levels or specificity of anti-KLH humoral responses.

Several lines of evidence demonstrate that tumor cells actively create a local and systemic immune suppressive environment [35-37]. The level of tumorload may therefore negatively correlate with the competence of a patients' immune system to respond to antigens such as KLH [38]. We investigated the humoral KLH responses in patients treated with DC-based vaccinations adjuvant to radical lymph node dissection, and thus without macroscopic disease (stage III), and in patients with distant metastatic and measurable disease, stage IV melanoma. We indeed confirm that anti-KLH Ab production was higher in stage III patients compared to patients with stage IV melanoma, which argues in favor of applying immunotherapy at earlier stages of disease.

Further analysis is warranted to investigate whether the $\mathrm{KLH}$-specific $\mathrm{Ab}$ response in the context of anti-cancer vaccines can be used as a surrogate biomarker for tumorspecific immune responses. The standardized ELISA presented here can facilitate in this effort as it allows interinstitutional comparisons of the humoral immunogenicity of KLH-containing vaccines.

Although we initially developed the quantitative antiKLH ELISA to monitor vaccine-induced immune responses, the assay allows quantification of humoral responsiveness as a measure of immunocompetence in individuals exposed to KLH. Since KLH elicits a primary immune response, intramuscular injection of KLH is the method of choice to investigate the capacity of an individual to respond to novel antigens, overcoming the confounding influence of previous exposure history [39].

Finally, because of its capacity as a nonspecific immune stimulator, KLH has been investigated as an intravesical agent to treat superficial bladder cancer [3]. Previously, it has been reported that the presence of anti-KLH antibodies was associated with treatment response [40]. In this respect, it is interesting to investigate whether in-depth analysis of the KLH-specific Ab responses in these patients can be an early predictor of therapy outcome.

In conclusion, we here present a sensitive and specific quantitative assay to measure KLH-specific Abs in human serum. We demonstrate that with this assay, it is now possible to monitor both the dynamics and absolute concentrations of KLH-specific humoral responses in individuals exposed to $\mathrm{KLH}$, for example to evaluate humoral immune competence. In addition, it may provide a valuable biomarker for the immunogenicity and clinical effectiveness of KLH-containing vaccines and therapies.

Acknowledgments This work was supported by grants from the Dutch Cancer Society (KUN2006-3699, KUN2009-4402), The Netherlands Organization for Scientific Research (NWO-Vidi-917.76.363, AGIKO-2008-2-4) and the Nijmeegs Offensief Tegen Kanker (NOTK) foundation.

Conflict of interests The authors declare that they have no conflict of interest.

Open Access This article is distributed under the terms of the Creative Commons Attribution License which permits any use, distribution, and reproduction in any medium, provided the original author(s) and the source are credited.

\section{References}

1. Harris JR, Markl J (1999) Keyhole limpet hemocyanin (KLH): a biomedical review. Micron 30(6):597-623

2. Swanson MA, Schwartz RS (1967) Immunosuppressive therapy. The relation between clinical response and immunologic competence. N Engl J Med 277(4):163-170

3. Perabo FG, Muller SC (2004) Current and new strategies in immunotherapy for superficial bladder cancer. Urology 64(3): 409-421

4. Schumacher K (2001) Keyhole limpet hemocyanin (KLH) conjugate vaccines as novel therapeutic tools in malignant disorders. J Cancer Res Clin Oncol 127(Suppl 2):R1-R2

5. Krug LM, Ragupathi G, Hood C, George C, Hong F, Shen R, Abrey L, Jennings HJ, Kris MG, Livingston PO (2012) Immunization with $\mathrm{N}$-propionyl polysialic acid-KLH conjugate in patients with small cell lung cancer is safe and induces IgM antibodies reactive with SCLC cells and bactericidal against group B meningococci. Cancer Immunol Immunother 61(1):9-18 
6. Gandhi RT, O'Neill D, Bosch RJ, Chan ES, Bucy RP, Shopis J, Baglyos L, Adams E, Fox L, Purdue L, Marshak A, Flynn T, Masih R, Schock B, Mildvan D, Schlesinger SJ, Marovich MA, Bhardwaj N, Jacobson JM (2009) A randomized therapeutic vaccine trial of canarypox-HIV-pulsed dendritic cells versus canarypox-HIV alone in HIV-1-infected patients on antiretroviral therapy. Vaccine 27(43):6088-6094

7. Melief CJ (2008) Cancer immunotherapy by dendritic cells. Immunity 29(3):372-383

8. Leonhartsberger N, Ramoner R, Putz T, Gander H, Rahm A, Falkensammer C, Bartsch G, Thurnher M (2007) Antigen-independent immune responses after dendritic cell vaccination. Cancer Immunol Immunother 56(6):897-903

9. Scheibenbogen C, Schadendorf D, Bechrakis NE, Nagorsen D, Hofmann U, Servetopoulou F, Letsch A, Philipp A, Foerster MH, Schmittel A, Thiel E, Keilholz U (2003) Effects of granulocytemacrophage colony-stimulating factor and foreign helper protein as immunologic adjuvants on the T-cell response to vaccination with tyrosinase peptides. Int J Cancer 104(2):188-194

10. Weide B, Pascolo S, Scheel B, Derhovanessian E, Pflugfelder A, Eigentler TK, Pawelec G, Hoerr I, Rammensee HG, Garbe C (2009) Direct injection of protamine-protected mRNA: results of a phase $1 / 2$ vaccination trial in metastatic melanoma patients. J Immunother 32(5):498-507

11. Verdijk P, Aarntzen EH, Lesterhuis WJ, Boullart AC, Kok E, van Rossum MM, Strijk S, Eijckeler F, Bonenkamp JJ, Jacobs JF, Blokx W, Vankrieken JH, Joosten I, Boerman OC, Oyen WJ, Adema G, Punt CJ, Figdor CG, De Vries IJ (2009) Limited amounts of dendritic cells migrate into the T-cell area of lymph nodes but have high immune activating potential in melanoma patients. Clin Cancer Res 15(7):2531-2540

12. Figdor CG, De Vries IJ, Lesterhuis WJ, Melief CJ (2004) Dendritic cell immunotherapy: mapping the way. Nat Med 10(5): 475-480

13. De Vries IJ, Lesterhuis WJ, Scharenborg NM, Engelen LP, Ruiter DJ, Gerritsen MJ, Croockewit S, Britten CM, Torensma R, Adema GJ, Figdor CG, Punt CJ (2003) Maturation of dendritic cells is a prerequisite for inducing immune responses in advanced melanoma patients. Clin Cancer Res 9(14):5091-5100

14. Jacobs JF, Punt CJ, Lesterhuis WJ, Sutmuller RP, Brouwer HM, Scharenborg NM, Klasen IS, Hilbrands LB, Figdor CG, De Vries IJ, Adema GJ (2010) Dendritic cell vaccination in combination with anti-CD25 monoclonal antibody treatment, a phase I/II study in metastatic melanoma patients. Clin Cancer Res 16(20): 5067-5078

15. Lesterhuis WJ, De Vries IJ, Schreibelt G, Lambeck AJ, Aarntzen EH, Jacobs JF, Scharenborg NM, van de Rakt MW, de Boer AJ, Croockewit S, van Rossum MM, Mus R, Oyen WJ, Boerman OC, Lucas S, Adema GJ, Punt CJ, Figdor CG (2011) Route of administration modulates the induction of dendritic cell vaccineinduced antigen-specific $\mathrm{T}$ cells in advanced melanoma patients. Clin Cancer Res 17(17):5725-5735

16. De Vries IJ, Lesterhuis WJ, Barentsz JO, Verdijk P, van Krieken $\mathrm{JH}$, Boerman OC, Oyen WJ, Bonenkamp JJ, Boezeman JB, Adema GJ, Bulte JW, Scheenen TW, Punt CJ, Heerschap A, Figdor CG (2005) Magnetic resonance tracking of dendritic cells in melanoma patients for monitoring of cellular therapy. Nat Biotechnol 23(11):1407-1413

17. Engell-Noerregaard L, Hansen TH, Andersen MH, Thor Straten $\mathrm{P}$, Svane IM (2009) Review of clinical studies on dendritic cellbased vaccination of patients with malignant melanoma: assessment of correlation between clinical response and vaccine parameters. Cancer Immunol Immunother 58(1):1-14

18. Kyte JA, Mu L, Aamdal S, Kvalheim G, Dueland S, Hauser M, Gullestad HP, Ryder T, Lislerud K, Hammerstad H, Gaudernack G (2006) Phase I/II trial of melanoma therapy with dendritic cells transfected with autologous tumor-mRNA. Cancer Gene Ther 13(10):905-918

19. Kyte JA, Kvalheim G, Lislerud K, thor Straten P, Dueland S, Aamdal S, Gaudernack G (2007) T cell responses in melanoma patients after vaccination with tumor-mRNA transfected dendritic cells. Cancer Immunol Immunother 56(5):659-675

20. Germeau C, Ma W, Schiavetti F, Lurquin C, Henry E, Vigneron N, Brasseur F, Lethe B, De Plaen E, Velu T, Boon T, Coulie PG (2005) High frequency of antitumor $T$ cells in the blood of melanoma patients before and after vaccination with tumor antigens. J Exp Med 201(2):241-248

21. De Vries IJ, Bernsen MR, Lesterhuis WJ, Scharenborg NM, Strijk SP, Gerritsen MJ, Ruiter DJ, Figdor CG, Punt CJ, Adema GJ (2005) Immunomonitoring tumor-specific T cells in delayed-type hypersensitivity skin biopsies after dendritic cell vaccination correlates with clinical outcome. J Clin Oncol 23(24): 5779-5787

22. Lopez MN, Pereda C, Segal G, Munoz L, Aguilera R, Gonzalez FE, Escobar A, Ginesta A, Reyes D, Gonzalez R, MendozaNaranjo A, Larrondo M, Compan A, Ferrada C, Salazar-Onfray F (2009) Prolonged survival of dendritic cell-vaccinated melanoma patients correlates with tumor-specific delayed type IV hypersensitivity response and reduction of tumor growth factor betaexpressing T cells. J Clin Oncol 27(6):945-952

23. Britten CM, Janetzki S, van der Burg SH, Huber C, Kalos M, Levitsky HI, Maecker HT, Melief CJ, O’Donnell-Tormey J, Odunsi K, Old LJ, Pawelec G, Roep BO, Romero P, Hoos A, Davis MM (2011) Minimal information about T cell assays: the process of reaching the community of $\mathrm{T}$ cell immunologists in cancer and beyond. Cancer Immunol Immunother 60(1):15-22

24. Janetzki S, Panageas KS, Ben-Porat L, Boyer J, Britten CM, Clay TM, Kalos M, Maecker HT, Romero P, Yuan J, Kast WM, Hoos A (2008) Results and harmonization guidelines from two largescale international Elispot proficiency panels conducted by the Cancer Vaccine Consortium (CVC/SVI). Cancer Immunol Immunother 57(3):303-315

25. Neelapu SS, Baskar S, Kwak LW (2001) Detection of keyhole limpet hemocyanin (KLH)-specific immune responses by intracellular cytokine assay in patients vaccinated with idiotype-KLH vaccine. J Cancer Res Clin Oncol 127(Suppl 2):R14-R19

26. Spazierer D, Skvara H, Dawid M, Fallahi N, Gruber K, Rose K, Lloyd P, Heuerding S, Stingl G, Jung T (2009) T helper 2 biased de novo immune response to Keyhole Limpet Hemocyanin in humans. Clin Exp Allergy 39(7):999-1008

27. Kelly BS, Levy JG, Sikora L (1979) The use of the enzymelinked immunosorbent assay (ELISA) for the detection and quantification of specific antibody from cell cultures. Immunology $37(1): 45-52$

28. Korver K, Zeijlemaker WP, Schellekens PT, Vossen JM (1984) Measurement of primary in vivo IgM- and IgG-antibody response to KLH in humans: implications of pre-immune IgM binding in antigen-specific ELISA. J Immunol Methods 74(2):241-251

29. Oyelaran O, Gildersleeve JC (2010) Evaluation of human antibody responses to keyhole limpet hemocyanin on a carbohydrate microarray. Proteom Clin Appl 4(3):285-294

30. Lesterhuis WJ, De Vries IJ, Schuurhuis DH, Boullart AC, Jacobs JF, de Boer AJ, Scharenborg NM, Brouwer HM, van de Rakt MW, Figdor CG, Ruers TJ, Adema GJ, Punt CJ (2006) Vaccination of colorectal cancer patients with CEA-loaded dendritic cells: antigen-specific T cell responses in DTH skin tests. Ann Oncol 17(6):974-980

31. Lesterhuis WJ, Schreibelt G, Scharenborg NM, Brouwer HM, Gerritsen MJ, Croockewit S, Coulie PG, Torensma R, Adema GJ, Figdor CG, De Vries IJ, Punt CJ (2011) Wild-type and modified gp100 peptide-pulsed dendritic cell vaccination of advanced melanoma patients can lead to long-term clinical responses 
independent of the peptide used. Cancer Immunol Immunother 60(2):249-260

32. Lane HC, Volkman DJ, Whalen G, Fauci AS (1981) In vitro antigen-induced, antigen-specific antibody production in man. Specific and polyclonal components, kinetics, and cellular requirements. J Exp Med 154(4):1043-1057

33. Stavnezer J (1996) Immunoglobulin class switching. Curr Opin Immunol 8(2):199-205

34. Waldmann TA (2007) Anti-Tac (daclizumab, Zenapax) in the treatment of leukemia, autoimmune diseases, and in the prevention of allograft rejection: a 25 -year personal odyssey. J Clin Immunol 27(1):1-18

35. Gajewski TF, Meng Y, Blank C, Brown I, Kacha A, Kline J, Harlin H (2006) Immune resistance orchestrated by the tumor microenvironment. Immunol Rev 213:131-145

36. Whiteside TL (2010) Inhibiting the inhibitors: evaluating agents targeting cancer immunosuppression. Expert Opin Biol Ther 10(7):1019-1035
37. Munn DH, Mellor AL (2007) Indoleamine 2,3-dioxygenase and tumor-induced tolerance. J Clin Invest 117(5):1147-1154

38. Golub SH, Rangel DM, Morton DL (1977) In vitro assessment of immunocompetence in patients with malignant melanoma. Int $\mathbf{J}$ Cancer 20(6):873-880

39. Grant RW, Mariani RA, Vieira VJ, Fleshner M, Smith TP, Keylock KT, Lowder TW, McAuley E, Hu L, Chapman-Novakofski K, Woods JA (2008) Cardiovascular exercise intervention improves the primary antibody response to keyhole limpet hemocyanin (KLH) in previously sedentary older adults. Brain Behav Immun 22(6):923-932

40. Jurincic-Winkler CD, von der Kammer H, Beuth J, Scheit KH, Klippel KF (1996) Antibody response to keyhole limpet hemocyanin $(\mathrm{KLH})$ treatment in patients with superficial bladder carcinoma. Anticancer Res 16(4A):2105-2110 